\title{
IFRS 7 and Risk Disclosure Policies: A Cross-Sectional Analysis of Italian Listed Banks
}

\author{
Sabrina Pucci, Marco Tutino \\ Roma Tre University, Roma, Italy
}

\begin{abstract}
This paper has a double aim, to give a theoretical evaluation of the disclosure model chosen by IASB referring to market risks of financial instruments and to analyze the practical solutions adopted in the case of a sample of listed banks and compliance of the information referring to risk in the "Notes" with the requirements of IFRS 7. In order to investigate the effectiveness of "IFRS 7, Financial Instruments", the research has been conducted considering Annual Report of a sample of 17 banking companies, all listed in the three-year period (2008-2010) in Italian financial markets. Studying a three-year period should reveal the performance of IFRS 7 in fostering market discipline by pressing banks to disclose more information regarding risk profile elements, mainly considering market risks such as interest rate risk, currency risk, and price risk, and then making financial disclosure more transparent. A content analysis has been adopted through a cross-sectional and time series study. The results underline that IFRS 7 improves the disclosure of market risks in financial statements compared with previous years even if a better equilibrium between qualitative and quantitative information could be found. In the sample analysed, substantial compliance with IFRS 7 requirements has been found, except for some particularly sensitive information. In some cases quantitative information cannot be considered sufficient to inform on potential impact of changes in risks exposure on the actual and expected value of income and equity of entities.
\end{abstract}

Keywords: IFRS 7, financial instruments, risk management, risk disclosure, accounting principles, banks

\section{Introduction}

This paper is part of the broader research project to verify how information on risk profile is reported in financial statements. The certainty that a stakeholder considers a reference point for his economic choices, regarding not only the profitability and the financial equilibrium of an enterprise but also his risk profile, determines the necessity to create a reporting system that is understandable both for those who "work" for the company and for those who "use" financial statements to make economic choices. Because risk is a complex and highly technical subject, born in insurance and then extended to financial and managerial studies, it is not easy to find the right model of financial reporting.

The aim of this research is to verify if the current solutions adopted by IASB for risk disclosure are "effective" and guarantee a "true and fair view" or if these solutions are only formal and not substantially useful for stakeholders. In fact a great problem may exist if accounting rules require a lot of information from

Sabrina Pucci, Ph.D., Full Professor of Business Administration, Department of Business Studies, Roma Tre University. Marco Tutino, Ph.D., Assistant Professor of Business Administration, Department of Business Studies, Roma Tre University.

Correspondence concerning this article should be addressed to Marco Tutino, Via Silvio d'Amico 77, Roma, Italy. E-mail: marco.tutino@uniroma3.it. 
companies without obtaining the desired benefits in terms of quality of information.

Even if it is clear that a lot of risks exist for companies (business risk, financial risk, pure and speculative risks), the risk profile that has been most analyzed from a disclosure point of view by IASB is financial instrument risk.

For this reason the paper examines whether the requirements stated by IFRS 7 referring to financial risk and in particular at this stage to market risk, have been applied with respect to:

- Disclosure;

- Compliance between "principles" and financial documents and the limitations encountered by passing from theoretical solutions to their practical application;

- Which of these limits could pose a real problem in the comprehension of risk for stakeholders?

The analysis of this paper considers only the banking sector. There are three main reasons for this choice:

- The great use that banks make of financial instruments compared with the industrial sector and in the common practice of banks to have organization, policies, controls and reports on financial risk trends. Therefore the risk disclosure of banks in financial statements should be both more complete (regarding financial instruments and model adopted and risk exposure) and more effective than risk disclosure of other entities;

- The relevant effects that the regulation of the Italian Supervisory Authority (Regulation No. 262 issued by Bank of Italy on 2005, December 22) has on the application of accounting principles to financial statements. The consequence is that it is not easy to separate the information in the Notes relevant for the supervisory authority from the information required by IFRS 7. Sometimes the other stakeholders exigencies are subordinated to supervisory ones;

- The choice made with Legislative Decree No. 38 issued on February 28, 2005 - transposition of the EU Regulations No. 1606/2002 - to apply IAS-IFRS both to individual and consolidated accounts in Italy.

A relevant sample chosen from the listed Italian banks is examined as proxy for the subjects that use IAS-IFRS principles and tries to verify the "efficiency" of IFRS 7 in presenting risk information and risk exposure in Annual Notes of companies. This is only the first step of the analysis; an improvement of the sample to include also insurance companies, other financial entities and main industrial groups will be necessary to evaluate whether different sectors apply the IFRS 7 prescriptions in a different manner and if the degree of disclosure on financial instrument risks can be related to specific business sectors.

\section{Literature Review}

The analysis, evaluation, and reporting of risk concerns several fields of study: Actuarial sciences studied the problem of quantifying risk and retention policies; finance mainly focused on the impact of risk on the value of firms; and management sciences analysed operational aspects in order to find tools to manage risk within companies.

In this review only some of the most recent works have been mentioned, those which either correlate risk and accounting or accounting and transparency. Little reference has been made to studies that aim to review the theoretical foundations of financial accounting or regarding the evolution that has been driven by the globalization of markets. Additional literature will be mentioned in the following paragraphs on methodology adopted for data analysis.

Many studies have analyzed the relationship between risk and transparency and the capacity of IAS/IFRS 
principles to give useful information to investors in order to make rational choices. Referring to the first aspects, a first stream of studies aimed to verify the impacts of IAS/IFRS on accounting and accounting standardization (Van Hulle, 2004; Ordelheide, 2004; Young, 2006; Macias \& Muino, 2011). On this research area, some studies analysed the effects of IAS/IFRS on the comparability of financial statements in different countries (Callao, Jarne, \& Lainez, 2007; Bartov, Goldberg, \& Kim, 2005; Delvaille, Ebbers, \& Saccon, 2006). The impacts deriving from the globalization of markets have been highly relevant, so some authors have analyzed on the nature and significance of the word "accounting" and the best practices for research methodology (Williams, 2009; Messner, 2009); some others have focused on the relation between truth, ethics, and accounting (Bayou, Reistein, \& Williams, 2011).

Because financial statements can be considered a "milestone" in the decisional process of investors, a significant number of studies underline the necessity to have a closer relationship between finance and accounting, especially in the evaluation of "risky cash flows" and in the definition of existing "risk factors" (Hopwood, 2009; Pope, 2010). Consider Pope’s (2010) arguments:

After experiencing the recent events of the deleveraging and credit crisis, if asked to identify a single main point of contact between future researches and practice in accounting and in finance, I would suggest risk. However, looking backwards, I would identify valuation as the most important common link between researchers and practitioners in finance and accounting. Of course value and risk are inherently interrelated constructs. (p. 90)

Additionally, recent accounting literature tried to find the relationship between financial reporting quality and assets pricing (Healy, Hutton, \& Papaleu, 1999; Lambert, Leuz, \& Verrecchia, 2008; Francis, Lafond, Olsson, \& Schipper, 2005).

Finally, a part of literature analysed the use of disclosure as a discretional tool for the management and credibility of reporting (Henry \& Leone, 2009; Mercer, 2005; Heinle \& Hofmann, 2009).

\section{IFRS 7: An Overview on Risk Disclosure Regarding Financial Instruments}

This principle was first issued in August 2005, and was subsequently modified following the financial crisis in 2008 and the need for a new principle regarding financial instrument evaluation. It is divided into two main parts. The first is related to the significance of financial instruments for financial position and performance, not considered in this paper. The second concerns the nature and extent of risks arising from financial instruments; this part is relevant for the research analysis: IFRS 7 principle gives the rules to give reliable disclosure on financial risks and the way to measure and manage them by entities.

Before commenting on the theoretical and empirical evaluation of the solutions adopted in IFRS 7 concerning risk disclosure, it may be useful to guarantee full comprehension of the logical process followed in the paper, to remember some principles stated in IFRS 7.

In the introduction, IASB affirms that The IFRS requires disclosure of:

(1) The significance of financial instruments for an entity's financial position and performance. These disclosures incorporate many of the requirements previously in IAS 32;

(2) Qualitative and quantitative information about exposure to risks arising from financial instruments, including specified minimum disclosures about credit risk, liquidity risk, and market risk. Qualitative disclosures describe management objectives, policies, and processes for managing those risks. Quantitative disclosures provide information about the extent to which the entity is exposed to risk, based on information provided internally to the entity's key management personnel. Used together with, disclosures provide an 
overview of the entity's use of financial instruments and the exposures to risks they create (IFRS 7, IN 5).

After the definitions of main financial risks in the Accounting Standard States (Appendix A, par. 31) as follows: "An entity shall disclose information that enables users of its financial statements to evaluate the nature and extent of risks arising from financial instruments to which the entity is exposed at the end of the reporting period".

The information to provide in order to give a complete view of enterprise risk profile is clustered in two main categories: quantitative information and qualitative information.

Figure 1 shows the risk framework disclosure as defined in IFRS 7.

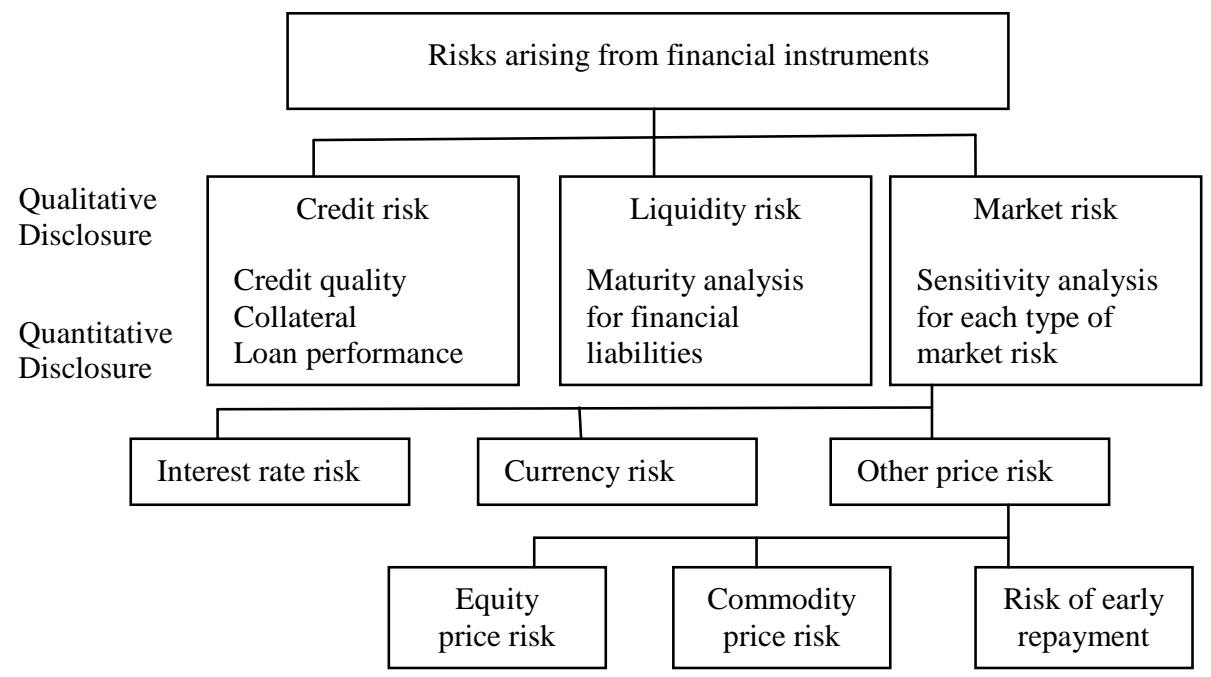

Figure 1. IFRS 7: Risk framework disclosure: elements.

In detail, referring to qualitative requirements (IFRS 7, par. 33) affirms that for each type of risk arising from financial instruments, an entity shall disclose:

(a) The exposures to risk and how they arise;

(b) Its objectives, policies, and processes for managing the risk and the methods used to measure the risk;

(c) Any changes in (a) or (b) from the previous period.

Referring to quantitative disclosure (IFRS 7, par. 34) states that an entity shall disclose:

(a) Summary quantitative data about its exposure to that risk at the end of the reporting period [...];

(b) The specific disclosure required by the following paragraphs referring to single types of risk.

After giving general principles on risk disclosure, IFRS 7 defines specific rules to apply to specific type of risk. In particular, for market risk-considered in this paper-IFRS 7, par. 40, states that an entity shall disclose:

(a) A sensitivity analysis for each type of market risk to which the entity is exposed at the end of the reporting period, showing how profit or loss and equity would have been affected by changes in the relevant risk variable that were reasonably possible at that date;

(b) The methods and assumptions used in preparing the sensitivity analysis;

(c) The changes from the previous period in the methods and assumptions used, and the reasons for such changes.

If a sensitivity analysis is applied, the entity must write in the Notes (par. 41): 
(a) An explanation of the method used in preparing such a sensitivity analysis, and of the main parameters and assumptions underlying the data provided;

(b) An explanation of the objective of the method used and of limitations that may result in the information not fully reflecting the fair value of the assets and liabilities involved".

IFRS 7, par. 41, also gives the possibility to explain the case in which sensitivity analysis is unrepresentative:

When the sensitivity analyses disclosed in accordance with paragraph 40 or 41 are unrepresentative of a risk inherent in a financial instrument (for example because the year-end exposure does not reflect the exposure during the year), the entity shall disclose that fact and the reason it believes the sensitivity analyses are unrepresentative.

It should be remembered that all the issues related to financial instruments are subject to relevant changes. For example, "IFRS 9, Financial Instruments” has already been issued but not yet endorsed by the European Community. Currently, a relevant process of analysis of IFRS 9 principles exists. The aim is to modify some parts of this principle to add a new class (FV_OCI) very close to FASB criteria even if some differences still exist in the definition of various classes.

Moreover, the new document "Exposure Drafts on Impairment of Financial Instruments and Hedge Accounting" have not been issued because of the abundance of comments. It is clear, new standards will have an impact on risk disclosure. Nevertheless, empirical analysis of this paper takes into account the present situation; some analysis and conclusions will need subsequent revision when the renewal process has been completed.

\section{Research Design}

\section{Methods Used in Previous Research}

This analysis covers disclosures in the financial statements of Italian listed banks between 2008 and 2010 following the idea of Evans and Taylor (1982), who recommend in-depth examination of published financial statements to measure the degree of disclosure. This multi-period analysis permits a more comprehensive picture of the implementation process and also the various methods used.

The framework chosen by Woods and Marginson (2004), Linsley, Shrives, and Crumpton (2006), and Woods, Dowd, and Humphrey (2009), who used content analysis as the main tool of research are also interesting. Others, such as Reynolds et al. (2008) used a survey-based analysis. Other research studies utilise cross-sectional models in which each type of disclosure index is regressed on proxy-related variables in order to detect the existence of a statistically significant relationship (Poshkwale \& Courtis, 2005; Mohan, 2006). Researchers have also tried to find all accessible measures of disclosure (Healy \& Palepu, 2001; Beattie, McInnes, \& Fearnley, 2001).

This study adopts a content approach similar to both Linsley et al. (2006) and Woods et al. (2009).

Linsley et al. (2006) used a sample of nine pairs of UK and Canadian banks, selected according to asset value, to highlight the differences in banking risk disclosure between the two markets and isolate differences that are country-specific.

Woods et al. (2009) used the top 25 banks of the world in terms of market capitalization. Their cross-country investigation, conducted on the Annual Reports of banks in three different time intervals ("start (2000), mid (2003), end (2006)”, p. 11), highlighted “changes in disclosure practices over time” (p. 15); unlike, 
Linsley et al. (2006) did not investigate on changes over time.

Two more important factors vary greatly in the literature: the sample size and the geographical or regional context. Reynolds et al. (2008) utilize the 100 Top Banks for their research in order to have a global view on the subject; Woods et al. $(2008,2009)$ use a smaller worldwide sample m of 25 banks.

KPMG (2009) narrow down the regional framework, focusing on 16 European banks; Woods and Marginson (2004) limited in the analysis, in terms of region and sample size, concentrating on only nine banks listed in the UK market (index FTSE 100).

\section{Methods Used in the Research}

Content analysis has been mainly adopted in this research. This is a transparent and flexible method that can also be used for both qualitative and quantitative research and allows comparative analysis between samples. In particular, this paper analyzes the content of Consolidated Annual Financial Reports adopting a replication logic (Eisenhardt, 1989), which allows each "analytic unit" observed to be considered as a "new experiment” useful to extend emerging theory (Yin, 1984).

The analysis applied in this paper is different from other content research for the following reasons:

- At this stage this paper limits the sample only to banks adopting IAS-IFRS principles in order to evaluate the impact of IFRS 7 on disclosure of group of homogeneous subjects and to find out whether if "discretional responses" to IFRS 7 prescriptions can be observed;

- This paper uses a multi-period analysis to verify whether in a homogenous group, a progressive approach to a "best practice" exists and if the level of risk disclosures sufficiently defined.

Annual reports from the three-year period (2008-2010) of a sample of 17 Italian listed banks have been considered to investigate the effectiveness of IFRS 7 Financial Instruments: Disclosures in the Italian banking industry. Observations on a three-year period should reflect the performance of IFRS 7 in fostering market discipline by pressing banks to disclose more information regarding risk profile elements, mainly considering market risks such as interest rate risk, currency risk, and price risk, and then making financial disclosure more transparent.

The period selected has been chosen in order to test if differences in disclosure of risk exposure and risk management processes and instruments in 2008 can be assessed relating to financial crisis.

\section{Sample, Data, and Documents Used in the Research}

The following information has been considered a sample of Italian listed banks and in particular the Consolidated Annual Reports, "Part E" of the notes—specifically dedicated to risk exposure for investors—has first been analysed to assess whether risk disclosure were compliant with IFRS 7, Financial Instruments: Disclosures. The analysis of the Notes can reveal if the information reported, even if compliant with IFRS 7 principle, can be considered sufficient to inform stakeholders on the effective exposure to market risks due to the position of financial instruments.

The sample of 17 listed banks has been selected considering different criteria:

- The completeness of available data;

- The need to include large, medium, and small banks to test whether size affects disclosure quality and quantity on market risk;

- The possibility that some differences depend on the core business of banks (Savings Bank or Regional Bank). 
The sample is reported in Table 1.

Table 1

Italian Bank Sample

\begin{tabular}{llcc}
\hline Bank & Reuters Industry & $\begin{array}{c}\text { Sales, FY 2010 } \\
\text { (Euro in Mln) }\end{array}$ & Sales in \% \\
\hline Unicredit & Regional Banks & 28,642 & $40.76 \%$ \\
Banca Intesa-San Paolo & Regional Banks & 17,500 & $24.91 \%$ \\
Banca Monte dei Paschi & Regional Banks & 6,472 & $9.21 \%$ \\
Banco Popolare & Regional Banks & 3,763 & $5.36 \%$ \\
Unione di Banche Italiane & S\&Ls/Savings Banks & 3,525 & $5.02 \%$ \\
Mediobanca & Regional Banks & 2,820 & $4.01 \%$ \\
Banca Popolare dell'Emilia Romagna & Regional Banks & 1,839 & $2.62 \%$ \\
Banca Popolare di Milano & Regional Banks & 1,257 & $1.79 \%$ \\
Cassa di Risparmio di Genova & Regional Banks & 1,103 & $1.57 \%$ \\
Credito Valtellinese & Regional Banks & 746 & $1.06 \%$ \\
Credito Emiliano & Regional Banks & 684 & $0.97 \%$ \\
Banca Popolare di Sondrio & Regional Banks & 633 & $0.90 \%$ \\
Banco di Sardegna & Regional Banks & 422 & $0.60 \%$ \\
Banca Popolare dell'Etruria & Regional Banks & 361 & $0.51 \%$ \\
Banco Desio e della Brianza & S\&Ls/Savings Banks & 258 & $0.37 \%$ \\
Credito Artigiano & Regional Banks & 230 & $0.33 \%$ \\
Banca Finnat & Investment Services & 7 & $0.01 \%$ \\
& & 70,262 & $100 \%$ \\
\hline
\end{tabular}

\section{Focus of Investigation}

Given that there are different classes of risk, each of them must be investigated in detail. For the purpose of this study, the research been focused on both qualitative and quantitative information of each class of market risks, as required by IFRS 7. In particular, the paper focuses on disclosure compliance with IFRS 7 for:

- Interest rate risk;

- Price risk;

- Currency risk.

Each type of risk has been analysed in order to assess the level of compliance of risk disclosure indicated in IRFS 7, such as:

(1) Qualitative disclosures:

- Exposures to risk;

- Methods used to measure risk;

- Objectives, policies, and processes for managing risk;

- Any changes from previous year.

(2) Quantitative disclosures:

- Quantitative exposure data;

- Parameters and assumptions of method;

- Effects on profit and loss and equity.

The paper also analyses the capacity of reported accounting data and information to provide a clear view on risk exposure and the processes to manage risk in the companies for stakeholders. 


\section{Reporting Results}

Results are shown in the following tables for each class of market risks. As shown in Tables 2 and 3, number " 1 " has been flagged when annual financial reporting of banks provides information on a single profile related to interest risk; otherwise, number " 0 " has been adopted when information is not provided, or not clearly provided as required by IFRS 7.

The table show results also expressed as percentages to offer a first level of indicators useful to evaluate the degree of compliance in risk disclosure of the sample.

Table 2

Qualitative Information

\begin{tabular}{llllll}
\hline Year & Exposure to risk & $\begin{array}{l}\text { Methods used } \\
\text { to measure risk }\end{array}$ & $\begin{array}{l}\text { Objectives for } \\
\text { managing risk }\end{array}$ & $\begin{array}{l}\text { Policies for } \\
\text { managing risk }\end{array}$ & $\begin{array}{l}\text { Processes for } \\
\text { managing risk }\end{array}$ \\
\hline & $\begin{array}{l}\text { Disclosed }=1 \\
\text { Not disclosed }=0\end{array}$ & $\begin{array}{l}\text { Disclosed }=1 \\
\text { Not disclosed }=0\end{array}$ & $\begin{array}{l}\text { Disclosed }=1 \\
\text { Not disclosed }=0\end{array}$ & $\begin{array}{l}\text { Disclosed }=1 \\
\text { Not disclosed }=0\end{array}$ & $\begin{array}{l}\text { Disclosed }=1 \\
\text { Not disclosed }=0\end{array}$ \\
\hline
\end{tabular}

Table 3

Quantitative Information

\begin{tabular}{llll}
\hline Year & $\begin{array}{l}\text { Summary of quantitative data } \\
\text { about exposure }\end{array}$ & $\begin{array}{l}\text { Parameters and assumptions } \\
\text { of method used }\end{array}$ & $\begin{array}{l}\text { Effects on profit and loss } \\
\text { and equity }\end{array}$ \\
\hline Disclosed $=1$ & $\begin{array}{l}\text { Disclosed }=1 \\
\text { Not disclosed }=0\end{array}$ & Not disclosed $=0$ & Disclosed $=1$ \\
Not disclosed $=0$
\end{tabular}

\section{Italian Listed Banks Case Study: Market Data and Results}

\section{Interest Rate Risk}

According to IFRS 7, interest rate risk is defined as "the risk that the fair value of future cash flows of a financial instrument may fluctuate as a result of changes in market interest rates”. Financial reporting principle IFRS 7, effective since January 2007, asks firms to disclose exposure to market risks. As for all market risks, IFRS 7 requires information on interest rate risk too. Assessing "the risks and uncertainties concerning a business enterprise's future cash flows” (AICPA, 1987, p. 3) is important to investors in order to evaluate the actual and future financial position and performance. For listed companies it is even more important due to the fact that share price is highly sensitive to news-related information. Therefore, management has to keep the company risk profile continuously under control.

Interest rate risk, which relates to the loss originating from unfavorable changes in interest rates, is one of the major financial (market) risks that a bank needs to manage. Moreover, for listed banks' changes in interest rates produce a direct impact on market value, expressed by market capitalization, depending on:

- Composition and maturity of assets and liabilities;

- Sensitivity of interest margin, which could be considered the same as operating margin in industrial companies.

In order to assess the degree of compliance of IFRS 7 of a sample of Italian listed banks, the following tables provide summary data reported in the Annual Consolidated Financial Report for fiscal years 2008-2010.

As required by IFRS 7, tables distinguish qualitative (exposure to risk, methods used to measure risk, objective, policies, and processes to manage risk, changes from previous year) and quantitative information 
(quantitative data on exposure, parameters, and assumptions of methods used, effects on profit and loss and equity).

Qualitative information. Results in Table 4 show that exposure to interest rate risk are reported by all banks in the sample. This result was expected because of the nature of bank core business. The management of interest risk exposure of financial instruments, both assets and liabilities, is an important part of bank' business.

Table 4

Interest Rate Risk-Qualitative Information, I

\begin{tabular}{|c|c|c|c|c|}
\hline \multirow[t]{2}{*}{ Year } & \multirow[t]{2}{*}{ Exposure to risk } & \multicolumn{2}{|c|}{$\begin{array}{l}\text { Methods used to measure } \\
\text { risk }\end{array}$} & \multirow[b]{2}{*}{$\begin{array}{l}\text { SENSITIVITY } \\
\text { (Duration gap, Interest } \\
\text { rates, other sensitivity } \\
\text { analysis) }\end{array}$} \\
\hline & & ALM & VAR & \\
\hline 2010 & 17 & 8 & 15 & 12 \\
\hline 2009 & 17 & 6 & 13 & 12 \\
\hline 2008 & 17 & 7 & 9 & 9 \\
\hline 2010 & $100 \%$ & $47 \%$ & $88 \%$ & $71 \%$ \\
\hline 2009 & $100 \%$ & $35 \%$ & $76 \%$ & $71 \%$ \\
\hline 2008 & $100 \%$ & $41 \%$ & $53 \%$ & $53 \%$ \\
\hline
\end{tabular}

There is a substantial compliance with IFRS 7 prescriptions referring to exposure to interest risk and general indications about the methods used to assess risks but only little data referring to the main assumptions used.

Looking at methods, it can be observed that less than $50 \%$ of banks still disclose on Asset and Liability Management (ALM), the practice of managing risks that arise due to mismatches between assets and liabilities (debts and assets)—but almost 88\% in the 2010 report use the VAR model to measure risk exposure and 71\% adopt various types of sensitivity analysis (duration gap, interest rate sensitivity and others) to help understand how "sensitive" the company's loan portfolio may be with respect to market rates. It is important to note that these results, both rising from $53 \%$ to $71 \%$ and $88 \%$ respectively, underline that all banks in the sample are trying to enhance their internal control system, adopting and also disclosing in the Notes, the VAR method and other models to measure portfolio risk exposure and related sensitivity to interest rates.

Table 5

Interest Rate Risk-Qualitative Information, II

\begin{tabular}{lllll}
\hline Year & $\begin{array}{l}\text { Objectives for } \\
\text { managing risk }\end{array}$ & $\begin{array}{l}\text { Policies for } \\
\text { managing risk }\end{array}$ & $\begin{array}{l}\text { Processes for } \\
\text { managing risk }\end{array}$ & Any changes \\
\hline 2010 & 17 & 8 & 15 & 12 \\
2009 & 17 & 6 & 13 & 12 \\
2008 & 17 & 7 & 9 & 9 \\
2010 & $100 \%$ & $82 \%$ & $76 \%$ & $6 \%$ \\
2009 & $100 \%$ & $71 \%$ & $71 \%$ & $6 \%$ \\
2008 & $100 \%$ & $47 \%$ & $53 \%$ & $6 \%$ \\
\hline
\end{tabular}

All banks report internal control system objectives, adopting different terms such as "controlling for risk exposure”, “maintaining high profitability”, or "enhancing market value”. 
Looking at policies adopted, results reported in Table 5 underline a growing interest of banks in reporting information in accordance with IFRS 7: from 47\% in 2008 to 82\% in 2010.

The same results emerge looking at disclosure on processes for managing risk. Some banks still refer to their internal operating manual instead of disclosing in the notes how they operated in terms of processes.

However, 76\% of the sample in 2010 provided information on processes compared with 53\% in 2008. Almost none of the banks reported on changes in policies and process relative to the previous year, just $6 \%$, corresponding to one bank in the whole sample.

Quantitative information. All banks in the sample report quantitative data on exposure in 2010. Only two banks did not for the fiscal year 2008, representing $12 \%$ of the sample (see Table 6).

Table 6

Interest Rate Risk-Quantitative Information

\begin{tabular}{lccc}
\hline Year & $\begin{array}{l}\text { Summary on quantitative } \\
\text { data about exposure }\end{array}$ & $\begin{array}{l}\text { Parameters and assumptions } \\
\text { of method used }\end{array}$ & $\begin{array}{l}\text { Effects on } \\
\text { profit or loss and equity }\end{array}$ \\
\hline 2010 & 17 & 4 & 17 \\
2009 & 17 & 4 & 16 \\
2008 & 15 & 3 & 9 \\
2010 & $100 \%$ & $24 \%$ & $100 \%$ \\
2009 & $100 \%$ & $24 \%$ & $94 \%$ \\
2008 & $88 \%$ & $18 \%$ & $53 \%$ \\
\hline
\end{tabular}

However it is important to note that almost none of the banks disclose on parameters and assumptions of method used. These results have to be kept in mind: disclosure on parameters and assumptions adopted in sensitivity analysis to measure interest rate risk exposure allows the investor to evaluate in more detail the actual exposure and the ability of banks to manage resources and adopt effective strategy for managing risk exposure.

\section{Price Risk}

Price risk is defined by IFRS 7, Appendix A, as:

The risk that the fair value of future cash flows of a financial instrument will fluctuate because of changes in market prices (other than those arising from interest rate risk or currency risk), whether those changes are caused by factors specific to the individual financial instruments or its issuer, or factors affecting all similar financial instruments traded in the market.

It is a very important financial risk, which banks need to manage. Moreover, for listed banks, changes in price produce a direct impact on market value, expressed by market capitalization, depending on:

- Composition and expiration of assets and liabilities;

- Sensitivity of price margin, which could be considered the same as operating margin in industrial companies.

In order to assess the degree of compliance with IFRS 7 of the selected sample of Italian listed banks, the following tables summarise the main data provided in annual financial reporting for the years 2008-2010.

As required by IFRS 7, data reported in tables distinguishes between qualitative (exposure to risk, methods used to measure risk, objectives, policies, and processes to manage risk, changes from previous year) and quantitative information (quantitative data on exposure, parameters, and assumptions of methods used, effects on profit and loss and equity). 
The scheme followed for the analysis is reported in the previous chapter and refers to the way of considering the presence or lack of information.

Qualitative information. The following tables include compliance data on items that are exposed to risk, the method is adopted to measure risk, the process used by the entity to manage risk.

Table 7

Price Risk-Qualitative Information, I

\begin{tabular}{|c|c|c|c|c|c|}
\hline Year & Exposure to risk & $\begin{array}{l}\text { Methods used } \\
\text { measure risk }\end{array}$ & $\begin{array}{l}\text { to Objectives } \\
\text { managing risk }\end{array}$ & $\begin{array}{l}\text { for Policies } \\
\text { managing risk }\end{array}$ & $\begin{array}{ll}\text { for Processes } & \text { for } \\
\text { managing risk } & \\
\end{array}$ \\
\hline 2010 & 16 & 15 & 10 & 7 & 16 \\
\hline 2009 & 17 & 16 & 10 & 7 & 16 \\
\hline 2008 & 17 & 16 & 10 & 6 & 15 \\
\hline 2010 & $94.1 \%$ & $88.2 \%$ & $58.8 \%$ & $41.2 \%$ & $94.1 \%$ \\
\hline 2009 & $100.0 \%$ & $94.1 \%$ & $58.8 \%$ & $41.2 \%$ & $94.1 \%$ \\
\hline 2008 & $100.0 \%$ & $94.1 \%$ & $58.8 \%$ & $35.3 \%$ & $88.2 \%$ \\
\hline
\end{tabular}

It is easy to see that, during the period considered there is a sufficient degree of compliance to IFRS principles (see Table 7). Most banks in 2010 and all of them in the two previous years, have been particularly careful to inform investors about the existence and characteristics of the main sources of price risk, the financial assets subject to more volatility in this direction and the methods of assessment and monitoring frequently used.

The objectives to be pursued in the management of risk and the policies underlying business risk management itself have not been completely achieved. Just over half of the banks examined (58\%) provide an indication of the objectives for managing risk (this percentage remains constant throughout the period considered) and a smaller percentage of companies (with a minimum value of $35 \%$ in 2008) described the guidelines provided by the company management. On the contrary, the information about the company structure, the divisions responsible, and processes defined to manage price risk appear sufficiently comprehensive. In the latter profile of information, the trend is actually increasing, with a rise of about $6 \%$ in “transparent” business from 2008 to today.

In the following Table 8, the types of methods used by banks to evaluate price risk exposure are shown. Because some banks use more than one mathematical/statistical model, the percentage sums may be more than $100 \%$.

Table 8

Price Risk-Qualitative Information, II

\begin{tabular}{|c|c|c|c|c|c|c|c|c|}
\hline Year & VAR & ALM & $\begin{array}{l}\text { Sensitivity } \\
\text { analysis }\end{array}$ & Stress test & $\begin{array}{l}\text { Internal } \\
\text { models }\end{array}$ & Other & $\begin{array}{l}\text { More th } \\
\text { one } \\
\text { instrument }\end{array}$ & $\begin{array}{l}\text { No indication } \\
\text { on } \\
\text { instruments }\end{array}$ \\
\hline 2010 & 15 & 2 & 7 & 10 & 2 & 12 & 15 & 2 \\
\hline 2009 & 16 & 1 & 7 & 10 & 2 & 12 & 15 & 1 \\
\hline 2008 & 16 & 1 & 7 & 10 & 2 & 12 & 15 & 1 \\
\hline 2010 & $100.0 \%$ & $13.3 \%$ & $46.7 \%$ & $66.7 \%$ & $13.3 \%$ & $80.0 \%$ & $100.0 \%$ & $11.8 \%$ \\
\hline 2009 & $100.0 \%$ & $6.3 \%$ & $43.8 \%$ & $62.5 \%$ & $12.5 \%$ & $75.0 \%$ & $93.8 \%$ & $5.9 \%$ \\
\hline 2008 & $100.0 \%$ & $6.3 \%$ & $43.8 \%$ & $62.5 \%$ & $12.5 \%$ & $75.0 \%$ & $93.8 \%$ & $5.9 \%$ \\
\hline
\end{tabular}

Information regarding the method used for assessing and monitoring price risk is present in $88 \%$ of the 
companies examined in 2010 and in 94\% of those analysed in 2009 and 2008. Most of them use the VAR method for the determination of risk capital during the three financial years considered. Even if VAR is the favorite model adopted, banks use different holding periods: one day (59\%); 10 days (53\%); two months (6\%); different holding periods referring to different types of asset (6\%). So the model is the same but assumptions are different.

The times that characterized holding periods are clearly a discretional element for management, which could have significant effects on evaluation.

However, VAR is not the only method used. In fact, with the exception of a few banks ( $9 \%$ on average over three years) that, in countertrend to the majority, do not indicate the risk measurement tools applied, it is clear that in no case is the estimate of risk assigned to the evaluation of a single indicator.

In 2008 and 2009, 6\% used the ALM method to contain the sources of risk. Subsequently, the percentage increased by more than $7 \%$.

Forty percent of banks in the sample perform sensitivity analysis, more than $60 \%$ use stress tests and 75\%-80\% use other evaluation and risk-monitoring models, often in support of VAR.

It should also be noticed that in the examined period, the banks have not changed the methods used to measure risk. This information is important but not as important as it might seem. The role of assumptions is essential in correct risk evaluation to have reliable results. As will be seen in the quantitative section, the assumption information is very limited. This determines formal compliance to IFRS 7 requirements but limits transparency for financial statement users.

Quantitative information. The indication of the amount of financial assets currently exposed to interest rate risk is not frequent: looking at Table 9, in 2010 only 52\% of selected banks guaranteed the respect of the information required by IFRS 7 on "summary quantitative data about exposure". Moreover, in this case, the trend is negative (-18\% from 2008 to 2010) with relevant effects on the completeness of disclosure. The situation is completely different regarding the indication of the parameters and assumptions used to estimate price risk and its impact on the income statement and shareholders' equity: the increase of $15 \%$ in this information given over the past three years underscores a growing willingness of banks to show in a transparent manner the impact of a negative evolution of risk on their accounts.

Table 9

Price Risk-Quantitative Information, I

\begin{tabular}{llll}
\hline Year & $\begin{array}{l}\text { Summary on quantitative } \\
\text { data about exposure }\end{array}$ & $\begin{array}{l}\text { Parameters and assumptions } \\
\text { of method used }\end{array}$ & $\begin{array}{l}\text { Effects on profit or loss and } \\
\text { equity }\end{array}$ \\
\hline 2010 & 9 & 15 & 15 \\
2009 & 10 & 15 & 15 \\
2008 & 12 & 13 & 12 \\
2010 & $52.9 \%$ & $88.2 \%$ & $88.2 \%$ \\
2009 & $58.8 \%$ & $88.2 \%$ & $88.2 \%$ \\
2008 & $70.6 \%$ & $76.5 \%$ & $70.6 \%$ \\
\hline
\end{tabular}

Referring to parameters and assumptions underlying the models, it must be highlighted that, although IFRS 7 is explicit in the kind of information that should be provided separately for each type of risk, there are frequent references to tables, graphs, and analysis related to other risks, in particular interest rates, and no separate disclosure. Table 10 summarizes this aspect. 
Table 10

Price Risk-Quantitative Information, II

\begin{tabular}{llll}
\hline Year & $\begin{array}{l}\text { Parameters and assumptions } \\
\text { of method used }\end{array}$ & $\begin{array}{l}\text { Specific disclosure on share } \\
\text { price (e.g., share price shock) }\end{array}$ & $\begin{array}{l}\text { Specific disclosure on } \\
\text { interest rate risk (e.g., interest } \\
\text { rate shifting) }\end{array}$ \\
\hline 2010 & 15 & 3 & 12 \\
2009 & 15 & 3 & 12 \\
2008 & 13 & 3 & 10 \\
2010 & $88.2 \%$ & $20.0 \%$ & $80.0 \%$ \\
2009 & $88.2 \%$ & $20.0 \%$ & $80.0 \%$ \\
2008 & $76.5 \%$ & $23.1 \%$ & $76.9 \%$ \\
\hline
\end{tabular}

It is easy to see that $88 \%$ of the sample in 2010 and 2009, and 76\% in 2008, provide information on parameters and assumptions underlying the model. Nevertheless, only 20\% in 2009-2010, and 23\% in 2008, fully respect the provisions of IFRS 7 with reference to the possible effects of unexpected changes in market prices. The remaining percentage fulfills the obligation only partially, and by an explicit reference to what may be previously analyzed.

\section{Currency Risk}

Currency risk is defined in IFRS 7 as "the risk that fair value of future cash flows of financial instruments will fluctuate because of changes in foreign exchange rates". Also in this case, financial statements of the sample are analyzed to verify, first of all, formal compliance of the "Notes" of financial statements to the requirements of IFRS 7 and secondly the transparency of the available information from a substantial point of view. As required by IFRS 7, data reported in tables distinguishes between qualitative (exposure to risk, methods used to measure risk, objectives, policies and processes to manage risk, changes from previous year) and quantitative information (type of hedging instruments used to cover risk, unbalance of position in currency, incidence of financial instruments used by bank in currency).

Qualitative information. As mentioned earlier, the first kind of analysis also refers to the formal compliance of data presented in the financial statement of the listed banks in the sample with the IFRS 7 qualitative prescription. A summary of this analysis is reported in Table 11.

It should be noted that the last column contains of Table 11 the results concerning an item that is not only qualitative but also quantitative. However, on the currency risk hypothesis in the VAR there is only a little data, so it is very difficult to evaluate information from a quantitative point of view.

Table 11

Currency Risk-Qualitative Information, I

\begin{tabular}{|c|c|c|c|c|c|}
\hline Year & Exposure to risk & $\begin{array}{l}\text { Methods used to } \\
\text { measure risk }\end{array}$ & $\begin{array}{l}\text { Objectives for } \\
\text { managing risk }\end{array}$ & $\begin{array}{l}\text { Policies for } \\
\text { managing risk }\end{array}$ & Currency VAR \\
\hline 2010 & 16 & 13 & 6 & 0 & 6 \\
\hline 2009 & 16 & 13 & 6 & 0 & 6 \\
\hline 2008 & 14 & 13 & 6 & 0 & 8 \\
\hline 2010 & $94.1 \%$ & $76.5 \%$ & $35.3 \%$ & $0.0 \%$ & $35.3 \%$ \\
\hline 2009 & $94.1 \%$ & $76.5 \%$ & $35.3 \%$ & $0.0 \%$ & $35.3 \%$ \\
\hline 2008 & $82.4 \%$ & $76.5 \%$ & $35.3 \%$ & $0.0 \%$ & $47.1 \%$ \\
\hline
\end{tabular}


It is easy to verify that compliance varies significantly according to requirements. Most banks define precisely the assets and liabilities exposed to currency risk (from $82 \%$ in 2008 to $94 \%$ in the subsequent years) and the methods used to evaluate this risk (76.5\%). Instead, the process used to manage currency risk and policy objectives are described respectively in the notes by half of the banks (56.25\%) and by none of them.

It must be highlighted that there is no relevant changes in qualitative disclosure from one year to another.

A lack of information is also present in the current VAR disclosure. Only a very limited number of banks give details on VAR referring to currency risk.

This approach is consistent with IFRS 7 prescriptions only in the case in which currency risk is not considered relevant. Some of the Notes highlight that currency risk may be considered irrelevant but looking at the amount of mismatches in the data, the real situation may be different from the theoretical one.

Investigating some aspects other than qualitative information, Table 12 shows the main methods used, during the three-year period analyzed, to determine currency risk exposure:

Table 12

Currency Risk-Qualitative Information, II

\begin{tabular}{llccll}
\hline Year & VAR & Simplified approach & Internal models & Others & No indication on model \\
\hline 2010 & $56.25 \%$ & $6.25 \%$ & $6.25 \%$ & $18.75 \%$ & $12.5 \%$ \\
2009 & $56.25 \%$ & $6.25 \%$ & $6.25 \%$ & $18.75 \%$ & $12.5 \%$ \\
2008 & $56.25 \%$ & $6.25 \%$ & $6.25 \%$ & $18.75 \%$ & $12.5 \%$ \\
2010 & $11.8 \%$ & $11.8 \%$ & $17.6 \%$ & $11.8 \%$ & $47.1 \%$ \\
2009 & $11.8 \%$ & $11.8 \%$ & $17.6 \%$ & $11.8 \%$ & $47.1 \%$ \\
2008 & $11.8 \%$ & $5.9 \%$ & $23.5 \%$ & $11.8 \%$ & $47.1 \%$ \\
\hline
\end{tabular}

It should be noted that in the case of currency risk, the weight of VAR is less than in the case of price and interest risk. The reason is probably connected with the relevance of currency risk in the management of assets and liabilities. Some banks point out that they have negligible exposure to this kind of risk (37.5\%), while some others affirm that currency risk is close to zero because of the hedge policy adopted (18.75\%). It should be noted also that there are no relevant changes in methods used by banks to determine the effects of currency risk.

Referring to the instruments used to manage this kind of risk, some banks describe the type of solution adopted (41.2\%), while others give only general information (from $17.6 \%$ to $23.5 \%$ ) and others do not indicate any information (47\%). Examples of hedging instruments adopted by banks, in the case of currency risk, are: plain vanilla, forex and currency swap and currency option.

As can be seen from data analyzed, no relevant change was made to qualitative disclosure on currency risk from the listed banks of the sample between 2008 and 2010.

Another important requirement of IFRS 7 is the disclosure of the possible effect of risk on equity. In the case of currency risk, this requirement is respected only in a limited number of companies (35\%), some ignoring this aspect, others making a general reference to a previous part of the notes where other market risks are analyzed.

Quantitative information. Although the quantitative information required by IFRS 7 on foreign exchange risk is equivalent to that for other market risks, it was found that, in general, the information provided was more limited. This limitation was often justified citing lack of relevance of this risk for balance sheets. The indication of the decision-making processes followed the basic parameters of the models of risk assessment, the impact of 
the VAR and the results of the sensitivity analysis are in some cases non-existent.

In these cases, however, some supplementary information has been found in the Notes because the banks, in compliance with what was decided in Regulation No. 262/2005 of the local Supervisory Authority, are obliged to give some data. Thus, it is possible to have some information that may at least partially satisfy the requirements of IFRS 7. For this reason, the discussion of quantitative elements connected with exchange rate risk presented in this paper varies from that referring to price and interest risk.

Examining quantitative data listed in the Notes, other interesting information about currency risk exposure may be found: the amount distributed by currency of: financial assets, other assets, financial liabilities, other liabilities and derivatives. It must be underlined that these amounts vary significantly from bank to bank. In the sample analyzed, the major amounts in most cases are in dollars but in some banks very large sums are also present in other currencies. In some cases situations of accounting mismatch between assets in one currency and the related liabilities are also presented.

For example, for one big banks of the sample, at the end of 2008 an accounting mismatch of 64,038 million dollars exists, at the end of 2010 the unbalance is equal to 325 million euro.

But also for small banks this problem of currency unbalance exists.

Other important information required by the Italian supervisory authority can be found in Table 13, from this data it is possible to analyze the investment policy of banks and its management policy.

Table 13 examines the incidence of every type of asset and liability in total assets and liabilities held by the bank in the year examined.

Table 13

Currency Risk-Quantitative Information

\begin{tabular}{llllll}
\hline Year & Financial assets & Other assets & Financial liabilities & Other liabilities & Derivatives \\
\hline 2010 & $3.79 \%$ & $0.10 \%$ & $2.53 \%$ & $0.03 \%$ & $13.54 \%$ \\
2009 & $4.11 \%$ & $0.11 \%$ & $4.10 \%$ & $0.04 \%$ & $19.43 \%$ \\
2008 & $4.66 \%$ & $12.18 \%$ & $5.19 \%$ & $29.50 \%$ & $12.52 \%$ \\
\hline
\end{tabular}

This information provides important indications about the modification of policies adopted by the bank sample in the three-year period in currency operations. Obviously this has an effect on the instruments used to manage risk. From these two last considerations the following conclusion can be drawn: quantitative data is essential to comprehend risk strategy.

IFRS 7 leaves companies completely free in relation to the data that they think is relevant to present in the financial statement because mandatory requirements for quantitative elements to be exhibited are very limited.

From data analysis, it is possible to create a system of early warning when some relevant changes in one or more items of the table happen. For example, a significant numbers of banks, in the 2008-2010 periods, changed the amount of derivatives existing in their portfolio: for instance, one of them in 2008 has derivatives for 198,526 million euro and in 2009 derivatives for 1,917 million euro.

It must be also highlighted that in some cases relevant changes have happened from one year to the next and also, in some cases, a change of approach in the use of derivatives.

\section{Future Developments and Conclusions}

As has been said in the Introduction, this paper contains only the first part of a research project on risk disclosure: for this reason, some limits should be removed in the second part of the analysis. For instance: 
- A sample enlargement to include data analysis from all the bank sector may be useful to validate some of the conclusions;

- A further enlargement to include in the sample also insurance and industrial companies may be very interesting to analyze if the sector of activities influences the way in which companies reply to IFRS 7 disclosure requirements;

- An extension of the analysis to consider credit and liquidity risks may be relevant to examine if the change of risk determines a modification in the information given in financial statements;

- An inclusion of data referring to 2005, 2006, 2007 financial statements may be helpful to verify what kind of progress has been made in financial risk disclosure since the application of IAS-IFRS;

- An enlargement to other European banks to determine if in the presence of the same principle (IFRS 7), the information about financial risk is similar or different depending on the nationality of the companies;

- An analysis of the impact of supervisory authority rules on the disclosure of risk may be interesting to evaluate if all of this information has to be included in financial statements or must be present in a separate statement;

- An analysis that leads to the construction of a risk disclosure index that permits measurement of the transparency level reached by a bank in its financial statement compared to others.

Even if the previously described limitations exist, some important data emerges from the analysis of data collected. The first element that is worth mentioning is the strong effort made by the IASB to find "principles" to permit investors to analyze the risk-return paradigm in financial statements. Certainly, the disclosure requirements stated by IFRS 7 require some data on exposure to financial risk and on how this exposure is managed. This was unthinkable previously especially regarding the management perspective and quantitative information. For these aspects, substantial compliance with the principles embodied in IFRS 7 is present.

From the quantitative point of view some further reflection appears necessary. The information shown, especially considering only that provided under IFRS 7 and not that required by the Italian supervisory authority, is quite different from entity to entity and therefore comparison between data from different companies is not easy for stakeholders. For example, to describe a model such as VAR without a clear indication of the assumptions and parameters used for evaluation may not be sufficient to understand results described by the firm in terms of risk. It must be reaffirmed that the role of assumptions is fundamental in risk evaluation to have reliable results. Lacking these assumptions there could be formal compliance with IFRS 7 requirements but limited transparency for financial statement users. The issue is difficult because while some further technical details may be useful, the complexity of the subject makes it difficult to create information that is both "understandable" and, at the same time, useful to the readers of financial statements.

Another conclusion is that IFRS 7 deals exclusively with financial risk, operational risk has not now been examined, despite potential significant effects on corporate life. It is hoped that the IASB in this phase of review of financial statement structures will also evaluate this aspect.

Finally, who may have benefits from this kind of risk disclosure analysis? It may be useful for researchers to validate the effectiveness in practice of the theoretical risk disclosure model; for standard setters as a sort of field test to verify if the prescriptions defined in accounting standards help to reach the desired aim; for managers to compare the results with the strategies applied; and for stakeholders to have a clear idea both of the information that is really useful for their decision processes and of the information that is not useful and relevant. 


\section{References}

AICPA-American Institute of Certified Public Accountants. (1987). Report of the task force on risks and uncertainties. New York: AICPA.

Bartov, E., Goldberg, S. R., \& Kim, M. (2005). Comparative value relevance among German, US and International Accounting Standards: A German stock perspective. Journal of International Accounting Auditing \& Taxation, 20(2), 95-119.

Bayou, M., Reistein, A., \& Williams, P. F. (2011). To tell the truth: A discussion on issues concerning truth and ethics in accounting. Accounting, Organizations and Society, 36, 109-124.

Beattie, V., McInnes, W., \& Fearnley, S. (2001). A methodology for analyzing and evaluating narratives in annual reports: A comprehensive descriptive profile and metrics for disclosure quality attributes. Accounting Forum, 28(3), 205-236.

Callao, S., Jarne, I., \& Lainez, J. A. (2007). Adoption of IFRS in Spain: Effect on the comparability and relevance of financial reporting. Journal of International Accounting Auditing \& Taxation, 16, 148-178.

Delvaille, P., Ebbers, G., \& Saccon, C. (2005). International financial reporting convergence: Evidence from three continental European countries. Accounting in Europe, 2, 137-164.

Eisenhardt, K. M. (1989). Building theory from case-study research. Academy of Management Review, 14(4), 532-550.

Evans, T. G., \& Taylor, M. E. (1982). Bottom line compliance with the IASC: A comparative analysis. The International Journal of Accounting, 18(1), 115-128.

Francis, J., Lafond, R., Olsson, P., \& Schipper, K. (2005). The market pricing of accruals quality. Journal of Accounting and Economics, 39(2, 295-327.

Healy, P. M., \& Palepu, K. G. (2001). Information asymmetry, corporate disclosure and the capital markets: A review of the empirical disclosure literature. Journal of Accounting and Economics, 31(1-3), 405-440.

Healy, P., Hutton, A., \& Papaleu, K. (1999). Stock performance and intermediation changes surrounding sustained increase in disclosure. Contemporary Accounting Research, 16(3), 485-520.

Heinle, M. S., \& Hofmann, C. (2009). Soft information and the stewardship value of accounting disclosure. University of Mannheim, or Spectrum, 33(2), 333-358.

Henry, E., \& Leone, A. J. (2009). Measuring qualitative information in capital markets research. Working Paper Series, School of Business University of Miami.

Hopwood, A. G. (2009). Exploring the interface between accounting and finance. Accounting, Organizations and Society, 34, 549-550.

KPMG. (2009). Focus on transparency-Trends in the presentation of financial statements and disclosure of information by European banks. Retrieved from http://www.kpmg.no/arch/_img/9500301.pdf

Laghi, E., Pucci, S., Tutino, M., \& Di Marcantonio, M. (2012). Fair value hierarchy in financial instruments disclosure: Is there transparency for investors? Evidence from the banking industry. Journal of Governance and Regulation, 1(4), 23-38.

Lambert, R., Leuz, C., \& Verrecchia, R. (2008). Accounting information, disclosure and the cost of capital. Journal of Accounting Research, 45(2), 385-420.

Linsley, P., Shrives, P., \& Crumpton, M. (2006). Risk disclosure: An exploratory study of UK and Canadian banks. Journal of Banking Regulation, 7(3), 268-282.

Macias, M., \& Muino, F. (2011). Examining dual accounting system in Europe. The International Journal of Accounting, 46, 51-78.

Mercer, M. (2005). The fleeting effects of disclosure forthcomingness on management's reporting credibility. The Accounting Review, 80(2), 723-744.

Messner, M. (2009). The limit of accountability. Accounting, Organizations and Society, 34, 918-938.

Mohan, S. (2006). Disclosure quality and its effect on litigation risk. Working Paper Series, University of Texas at Austin, Department of Finance.

Ordelheide, D. (2004). The politics of accounting: A framework. In D. Leuz, D. Pfaff, \& A. G. Hopwood (Eds.), The economics and politics of accounting, international perspectives on research trends, policy and practice. Oxford: Oxford University Press.

Pope, P. F. (2010). Bridging the gap between accounting and finance. The British Accounting Review, 42, 88-102.

Poshkwale, S., \& Courtis, J. (2005). Disclosure level and cost of equity capital: Evidence from the banking industry. Managerial and Decision Economics, 26(7), 431-444. 
Pucci, S., Tutino, M., \& Marulli, E. (2012). Comparative analysis of risk management and risk disclosure in the banking sector, Italian vs. world practices. The International Journal of Management and Business, 3, 34-46.

Reynolds, D., Raposo, M., \& Lloyd, A. (2008). How the world largest banks discuss their risks. Retrieved from http://www.algorithmics.com/EN/media/pdfs/Algo-RA0308 RiskReport0212.pdf

Van Hulle, K. (2004). From accounting directive to international accounting standards. In D. Leuz, D. Pfaff, \& A. G. Hopwood (Eds.), The economics and politics of accounting, international perspectives on research trends, policy and practice. Oxford: Oxford University Press.

Williams, P. F. (2009). Reshaping accounting research: Living in the world in which we live. Accounting Forum, 33, $274-279$.

Woods, M., \& Marginson, D. (2004). Accounting for derivatives: An evaluation of reporting practice by UK banks. European Accounting Review, 13(2), 373-390.

Woods, M., Dowd, K., \& Humphrey, C. (2009). Market risk reporting by the world's top banks: Evidence on the diversity of reporting practice and the implications for international accounting harmonization. Spanish Accounting Review, 11(2), 9-42.

Yin, R. K. (1984). Case study research: Design and methods. Newbury Park, Sage, CA.

Young, J. J. (2006). Making up users. Accounting, Organizations and Society, 31(6), 579-600. 